\title{
Genetics to unlock secrets of our African past
}

Michael Cherry, Stellenbosch

Archaeologists and geneticists could soon be working together to investigate the genetic diversity of our human ancestors in Africa, a meeting on the "Human Genome and Africa" was told last month.

Chris Stringer of London's Natural History Museum told the meeting, organized by South Africa's Human Sciences Research Council (HSRC), that the identification of well-preserved fossil hominids and analysis of their DNA could answer key questions about the origin of our species. It is widely accepted that humans evolved from hominids that left Africa during the past 200,000 years - but little is known about the location or genetic diversity of the African groups.

African fossil hominids have very diverse morphology compared with those from Europe, where only two distinct groups the Neanderthals and Cro-Magnons (the progenitors of modern humans) - have been found. "The sheer size of Africa may mean that it could conserve diversity in genetic material, and innovations in human behaviour, better than other areas," Stringer says.

In Europe, Neanderthal DNA has already been sequenced successfully, but ancient DNA has not yet been extracted from African hominid fossils. According to Julia LeeThorp, an archaeologist at the University of Cape Town, very little organic material is preserved in African fossils more than 10,000 years old, because preservation requires cool, dry conditions. "One would have to look specifically for sites with extraordinary preservation conditions," she says.

Archaeologists have some potential sites in mind in South Africa. "I think that there would be considerable interest in funding this kind of research," says meeting organizer Wilmot James, director of the HSRC's social cohesion and integration programme.

But permission for excavations, previously the responsibility of the National Monuments Council, was recently devolved to the country's nine provinces. Most provinces lack the infrastructure to administer this mandate, resulting in an effective moratorium on excavations. There is also currently a moratorium on the export of fossil samples for research, requiring the genetic analysis of any samples to be done locally.

Stringer thinks the great diversity of relatively recent hominids in Africa reflects genetic bottlenecks generated as a result of the climate change that occurred between 400,000 and 10,000 years ago, forcing populations to withdraw to small refuges. The surviving populations in these areas could have evolved rapidly in response to sexual selection based on, for example, facial features - leading to a diverselooking collection of hominids across the continent. "It is quitelikely that these ancestors did

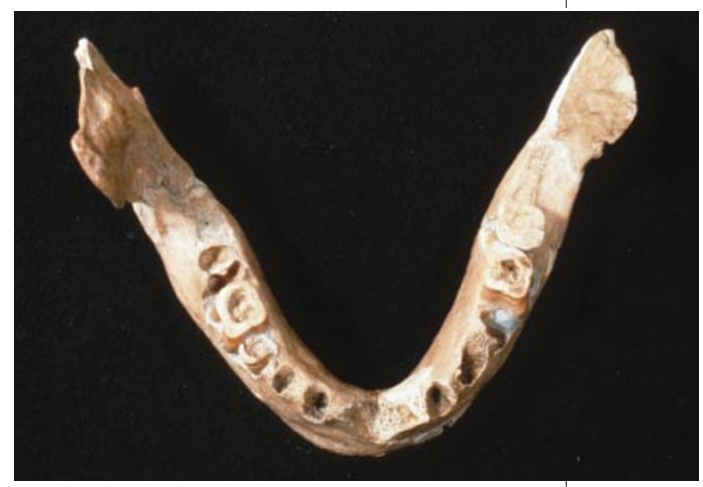

DNA from artefacts such as this 100,000-year-old jawbone could shed light on hominid diversity.

not closely resemble any extant racial group," says Stringer, "as modern regional features are not seen in skulls more than 30,000 years old, from either Africa or other continents."

Several speakers at the conference, which was held on 19-22 March and attracted 350 scientists and officials from 17 African and 13 other countries, called for Africa to move faster to use genomics in medicine and social science. Gordon Dougan, director of the Centre for Molecular Microbiology and Infection at Imperial College, London, said that African scientists need to master genomics so they can develop their own vaccines and drugs, outside the control of multinational companies.

\section{Axeing of website article sparks row at Max Planck}

\section{Alison Abbott, Munich}

The Max Planck Institute for Plant Breeding

Research in Cologne has removed the detailed description of 'intelligent design' from its website, following complaints from scientists that it was inconsistent with the laboratory's scientific mission.

The article, which was posted by WolfEkkehard Lönnig, a theorist at the institute, discusses the idea that an intelligent force must be responsible for the origin of the

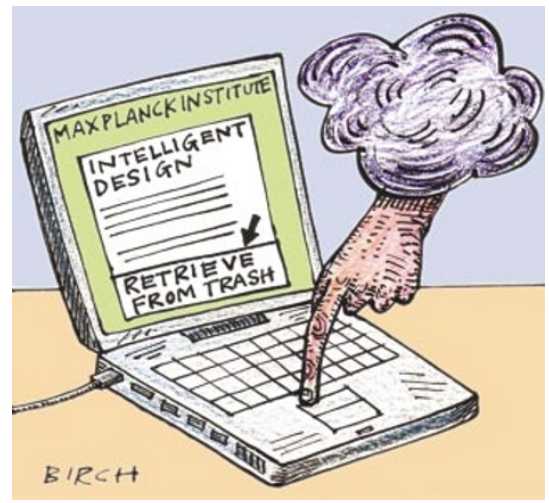

Universe and for the diversity of life forms. Known as intelligent design, this theory rejects natural selection, and has been portrayed by its opponents as a 'front' for creationism (see Nature 416, 250; 2002).

Earlier this month, Peter Gruss, president of the Max Planck Society, asked the four directors of the Cologne institute to provide a scientific justification for Lönnig's pages. Lönnig posted the material five years ago, and the site has since received over 35,000 hits. A disclaimer identifying the article as a personal opinion was added in 2001, following earlier complaints.

"Only scientific issues should be discussed on a Max Planck site," says Gruss. And last week, Lönnig's pages were removed from the institute's site, pending a directors' meeting on 28 April to determine their fate.

Ulrich Kutschera, an evolutionary biologist at the University of Kassel, has campaigned against the presence of the material on an official Max Planck website, branding it "pseudoscience". "It is fine as a personal opinion expressed on a personal website, but not on the official site of a scientific organization of international status," he says.

Many evolutionary biologists share Kutschera's concerns: Axel Meyer of the University of Constance, for example, says that he was "shocked" by the contents of the pages. But others, such as Diethard Tautz at the University of Cologne and Svante Pääbo at the Max Planck Institute for Evolutionary Anthropology in Leipzig, are more circumspect, saying that independent opinions should be permitted. Tautz, however, says it might be more appropriate for such opinions to be aired at "an institute of philosophy" than at the Max Planck.

Lönnig is displeased by the removal of his discussion. "No one is happy when someone switches off the information flow of what he thinks is right," he says. And Heinz Saedler, one of the institute's directors, who has supported Lönnig and published jointly with him, says that although he doesn't believe in intelligent design himself, he enjoys discussing it with Lönnig. 